\title{
Hydrogen Peroxide Formation and Catalase Activity in the Lactic Acid Bacteria
}

\author{
BY R. WHITTENBURY \\ Department of Bacteriology, School of Agriculture, Edinburgh
}

(Received 9 September 1963)

\begin{abstract}
SUMMARY
Some lactic acid bacteria formed detectable $\mathrm{H}_{2} \mathrm{O}_{2}$ and some did not, regardless of their preference or requirement for aerobic or anaerobic conditions. Whether or not $\mathrm{H}_{2} \mathrm{O}_{2}$ was formed depended in some instances on the substrate used as energy source. Two $\mathrm{H}_{2} \mathrm{O}_{2}$-splitting activities were encountered though never in the same organism. One, named pseudocatalase activity, was insensitive to $0.01 \mathrm{M}$-azide or $0.01 \mathrm{M}$-cyanide and appeared to be the action of an acid-sensitive non-haem-containing enzyme detectable in some leuconostocs and pediococci when grown in media containing a low concentration of glucose. The second, named catalase activity, was detected in a number of lactobacilli, leuconostocs, streptococci and pediococci grown on media containing haematin or heated blood; presumably these organisms are able to synthesize the apoenzyme but not the prosthetic group of catalase. This activity was inhibited by $0.01 \mathrm{M}$-azide or $0.01 \mathrm{M}$-cyanide; it was not acid-sensitive. There was little correlation between $\mathrm{H}_{2} \mathrm{O}_{2}$-splitting activity and the preference or requirement of the organisms for aerobic or anaerobic conditions, or between $\mathrm{H}_{2} \mathrm{O}_{2}$-splitting activity and $\mathrm{H}_{2} \mathrm{O}_{2}$ formation. Of a few organisms examined, some appeared capable of forming cytochromes when grown in media containing heated blood. One showed traces of a cytochrome whether grown in the presence or absence of heated blood.
\end{abstract}

\section{INTRODUCTION}

Evidence has accumulated to show that oxygen can be of benefit in the utilization of sugars and polyhydroxy alcohols by certain lactic acid bacteria. Gunsalus \& Sherman (1943) found that a strain of Streptococcus faecalis (which would now be classified as $S$. faecium) and other lactic acid bacteria utilized glycerol only in presence of oxygen. Gunsalus \& Umbreit (1945), with the same strain of $S$. faecalis, recorded that one mole lactate and one mole hydrogen peroxide were formed per mole glycerol and mole oxygen used. Such a reaction indicates that oxygen serves as an exogenous hydrogen acceptor, accepting two atoms of hydrogen from glycerol and thereby allowing the balanced fermentation of glycerol to proceed. Dolin (1955) showed that oxygen could be used advantageously in the utilization of glucose by a strain of $S$. faecalis. Under anaerobic conditions, the pyruvate normally formed acted as a hydrogen acceptor in the balanced fermentation of glucose to lactic acid. In presence of oxygen, however, pyruvate was relieved of its role as oxidant and was further utilized to form an additional mole of adenosine triphosphate/mole triose. Theoretically, therefore, glucose might yield aerobically twice as much energy as anaerobically. Dobrogosz \& Stone (1959) reported a strict requirement for oxygen 
by certain pediococci which utilized glycerol; Whittenbury (1963) gave examples where oxygen was of benefit or was required in the utilization of certain substrates by certain lactic acid bacteria. The present paper gives the results of studies about hydrogen peroxide formation and hydrogen peroxide splitting by lactic acid bacteria and some preliminary findings about cytochrome formation by some of these organisms. A note on the catalase-like activity has already been published (Whittenbury, 1960).

\section{METHODS}

Organisms. Lactobacilli, streptococci, leuconostocs, pediococci and aerococci obtained from sources described previously (Whittenbury, 1963) were examined. The pediococci were classified according to Nakagawa \& Kitahara (1959).

Media. Basal medium agar was meat extract (Lab Lemco), 0.5 g.; yeast extract (Difco), 0.5 g.; Tween 80, 0.05 ml.; $\mathrm{MnSO}_{4} .4 \mathrm{H}_{2} \mathrm{O}, 0.01 \mathrm{~g}$; agar (Davis), $1.5 \mathrm{~g}$.; made up to $100 \mathrm{ml}$. with tap water. The $\mathrm{pH}$ value was adjusted as required and the medium autoclaved at $121^{\circ}$ for $15 \mathrm{~min}$.

The 'inoculum medium ' was similar to the basal medium agar with the exceptions that agar was omitted and glucose $(0.5 \%, \mathrm{w} / \mathrm{v})$ added and the medium adjusted to pH 6.5.

Soft agar medium, which was used for showing oxygen relationships, was prepared and inoculated as described previously (Whittenbury, 1963) with the addition of $\mathrm{MnSO}_{4}, 0.01 \%$ (w/v).

Manganese dioxide (MDO) agar was basal medium agar adjusted to $\mathrm{pH} 6.5$ and containing $1 \%(\mathrm{w} / \mathrm{v})$ of a separately sterilized sugar or polyhydroxy alcohol; this was poured in a plate and then a very thin layer of the same medium (1-2 ml.) to which had been added $4 \%(\mathrm{w} / \mathrm{v})$ manganese dioxide (black tech. Harrington Bros. Ltd.) was poured on top. This medium is a variation of the pyrolusite agar described by Kneteman (1947). Clearing of the manganese dioxide under and around the bacterial growth indicates $\mathrm{H}_{2} \mathrm{O}_{2}$ formation.

Heated blood $o$-dianisidine (HBD) agar was made as follows. Basal medium agar (90 ml. adjusted to $\mathrm{pH} \mathrm{6.5)} \mathrm{was} \mathrm{melted} \mathrm{and} 5 \mathrm{ml}$. of a $1+1$ mixture of defibrinated ox blood and water added and the whole heated at $100^{\circ}$ for $15 \mathrm{~min}$. 0 -Dianisidine $\left(0.1 \mathrm{~g}\right.$. in $5 \mathrm{ml}$. sterile water heated at $100^{\circ}$ for $15 \mathrm{~min}$.) was transferred whilst still hot by a wide-mouthed pipette to the melted agar. The medium, cooled to $48^{\circ}$, was completed by adding a separately sterilized sugar or polyhydroxy alcohol solution (final concentration $1 \%, \mathrm{w} / \mathrm{v}$ ) and poured in plates. This medium was a variation of the media used by Penfold (1922), Berger (1953) and Kraus, Nickerson, Perry \& Walker (1957). Benzidine was replaced by 0 -dianisidine because of the carcinogenic property of the benzidine. Heated blood was used because many organisms produced a dark brown growth on media containing unheated blood, irrespective of the presence of $o$-dianisidine or the formation of $\mathrm{H}_{2} \mathrm{O}_{2}$. The production of $\mathrm{H}_{2} \mathrm{O}_{2}$ was indicated by the growth and the surrounding medium becoming dark brown or black, haem compounds having a peroxidase-like reaction in the oxidation of $o$-dianisidine by peroxide.

Heated blood (HB) agar was basal medium agar $(95 \mathrm{ml}$; $\mathrm{pH} 6 \cdot 8-7)$ containing $1 \%(\mathrm{w} / \mathrm{v})$ glucose autoclaved at $121^{\circ}$ for $15 \mathrm{~min}$. After adding to the molten medium $5 \mathrm{ml}$. of a $1+1$ mixture of defibrinated ox blood + water, the complete medium was heated at $100^{\circ}$ for 15 min. 
Haematin agar was basal medium agar (pH 6.8-7) with $1 \%(\mathrm{w} / \mathrm{v})$ glucose autoclaved at $121^{\circ}$ for $15 \mathrm{~min}$. Haematin $(50 \mu \mathrm{g} . / \mathrm{ml}$.) was then added from a stock solution $(50 \mathrm{mg}$. haematin in $10 \mathrm{ml}$. water and sufficient $0.1 \mathrm{~N}-\mathrm{NaOH}$ to dissolve the haematin) which had been heated at $100^{\circ}$ for $15 \mathrm{~min}$.

Carbohydrates and polyhydroxy alcohols when not autoclaved in the media were used as distilled water solutions sterilized by Seitz-filtration.

Detection of hydrogen peroxide formation. Plates of MDO agar and HBD agar were inoculated by streaking with a capillary pipette containing an $18 \mathrm{hr}$ old inoculum. Cultures were examined daily for 7 days.

Detection of hydrogen peroxide-splitting activity. Four media were used: HB agar,

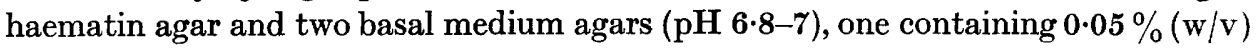
glucose and the other $1 \%(\mathrm{w} / \mathrm{v})$ glucose. The first two media were prepared as plates, the last two as slopes. All were inoculated by streaking with a capillary pipette containing an $18 \mathrm{hr}$ old culture. Activity was recognized visually by effervescence on the addition of hydrogen peroxide (' 10 vol.') to heaped growth. Negative results were checked by placing heaped growth into $\mathrm{H}_{2} \mathrm{O}_{2}$. The media themselves showed no effervescence on adding $\mathrm{H}_{2} \mathrm{O}_{2}$.

The action of bacterial suspensions on hydrogen peroxide. Bacteria harvested from nutrient agar cultures in flat bottles which had been inoculated aerobically for 15-18 hr were washed twice with sterile tap water and resuspended in $0.07 \mathrm{M}$ phosphate buffer ( $\mathrm{pH}$ 6.5). Bacterial suspensions (0.5 ml. equiv. 10-15 mg. dry wt.) were distributed in Durham tubes which were placed in a water bath at $30^{\circ}$. When the effect of haematin or protoporphyrin IX was being tested, $0 \cdot 1 \mathrm{ml}$. of a stock solution or a distilled water dilution of a stock solution of these substances was added to a tube. Stock solutions were prepared by dissolving $50 \mathrm{mg}$. haematin or protoporphyrin IX in a solution of $9 \mathrm{ml}$. distilled water $+1 \mathrm{ml}$. triethanolamine. Distilled water solutions of sodium azide and potassium cyanide were added $(0 \cdot 1 \mathrm{ml}$.) to bacterial suspensions to provide the required concentrations. The ability to split $\mathrm{H}_{2} \mathrm{O}_{2}$ was recognized by effervescence on adding hydrogen peroxide (' 10 vol.').

Determination of the rate of hydrogen peroxide-splitting activity. Bacterial suspensions were prepared as described above and the method of Herbert (1955) used to determine their hydrogen peroxide-splitting activity. This involved adding bacterial suspensions to a solution of $\mathrm{H}_{2} \mathrm{O}_{2}$ in test-tubes, the termination of enzyme activity by adding $\mathrm{H}_{2} \mathrm{SO}_{4}$, the addition of $\mathrm{KI}$ and catalytic amounts of ammonium molybdate, and the titration of the free iodine released by the action of residual peroxide by standard $\mathrm{Na}_{2} \mathrm{~S}_{2} \mathrm{O}_{3}$ with starch as indicator. When determining the effect of haematin, protoporphyrin IX, sodium azide or potassium cyanide on $\mathrm{H}_{2} \mathrm{O}_{2}$-splitting activity, $0.1 \mathrm{ml}$. amounts of solutions prepared as described above were added to the bacterial suspensions before these were placed in the $\mathrm{H}_{2} \mathrm{O}_{2}$ solution. A stock solution of $\mathrm{H}_{2} \mathrm{O}_{2}$ was prepared by diluting hydrogen peroxide (' 20 vol.') with $0.07 \mathrm{M}$-phosphate buffer ( $\mathrm{pH} 6.5$ ) to give about $120 \mu$ mole $\mathrm{H}_{2} \mathrm{O}_{2} / 5$ ml. stock solution.

Oxygen uptake by bacterial suspensions containing glucose at $30^{\circ}$. This was measured by conventional Warburg procedures with air as gas phase. Bacteria harvested from a 15-18 hr aerobic glucose nutrient agar culture were washed twice with sterile tap water, suspended in 0.07 $\mathrm{M}$-phosphate buffer ( $\mathrm{pH} \mathrm{6.8)}$ and $2 \mathrm{ml}$. (equiv. 5-10 mg. dry wt. bacteria) were placed in the main compartment. After temperature 
equilibration $1 \mathrm{ml}$. of glucose solution was added from the side arm to give a final glucose concentration of $0 \cdot 1 \mathrm{M}$ in $3 \mathrm{ml}$. fluid volume. The centre well contained $0 \cdot 2 \mathrm{ml} .2 \mathrm{~N}-\mathrm{KOH}$ and a filter-paper wick.

Incubation. All the cultures were grown at $30^{\circ}$ and all the experiments with bacterial suspensions were carried out at $30^{\circ}$.

\section{RESULTS}

\section{Hydrogen peroxide formation}

Tests were carried out with MDO and HBD agars containing different substrates as energy sources, and in some instances with the basal (unsupplemented with sugar or polyol) HBD agar. The results in Table 1 support four main conclusions: (1) not all the lactic acid bacteria tested formed detectable amounts of $\mathrm{H}_{2} \mathrm{O}_{2} ;(2) \mathrm{H}_{2} \mathrm{O}_{2}$ might accumulate during the utilization of one substrate but not of another; (3) a preference or a requirement for aerobic or anaerobic conditions, as judged by growth in soft agar, was not necessarily related to $\mathrm{H}_{2} \mathrm{O}_{2}$ accumulation; (4) $\mathrm{H}_{2} \mathrm{O}_{2}$ accumulation might be a useful taxonomic characteristic (this latter aspect will be considered subsequently).

When inocula were grown anaerobically or were taken from static deep cultures incubated aerobically, traces of $\mathrm{H}_{2} \mathrm{O}_{2}$ sometimes appeared in the first aerobic subculture on MDO or HBD media but not on serial transfer on these media. This behaviour was not observed with inocula from nutrient agar slope cultures grown aerobically; these were consistent and either produced or did not produce $\mathrm{H}_{2} \mathrm{O}_{2}$ on serial aerobic subculture.

Representative organisms which formed $\mathrm{H}_{2} \mathrm{O}_{2}$ (11 strains) and others which did not do so (9 strains) were examined manometrically for oxygen uptake with glucose as substrate. All were active: in 12 of 20 cases the $Q_{0_{2}}$ was in the range 20-40. Bacteria harvested at $15-18 \mathrm{hr}$ were much more active than those harvested at 24-36 hr; this was especially marked with some of the $\mathrm{H}_{2} \mathrm{O}_{2}$-forming cultures. Oxygen uptake with and without the formation of detectable amounts of $\mathrm{H}_{2} \mathrm{O}_{2}$, together with the evidence of the presence of flavoprotein oxidases and peroxidases in lactic acid bacteria (Dolin, 1953, 1955, 1957; Niederpruem \& Hackett, 1958; Strittmatter, 1959), suggests that the significant difference between these strains, with respect to $\mathrm{H}_{2} \mathrm{O}_{2}$ production, is that organisms which form $\mathrm{H}_{2} \mathrm{O}_{2}$ possess flavoprotein oxidases whereas the others possess also, or form adaptively, flavoprotein peroxidases. Since all our strains were not tested for oxygen uptake, it is possible that some did not form peroxide because they were unable to utilize oxygen, for example, as reported for a strain of Leuconostoc mesenteroides by Johnson \& McCleskey (1957).

\section{Hydrogen peroxide-splitting activity}

Since $\mathrm{H}_{2} \mathrm{O}_{2}$ may be toxic it is obviously an advantage to an organism to be able to destroy any which it may form. Several lactic acid bacteria do so peroxidatively (Greison \& Gunsalus, 1943; Douglas, 1947; Seeley \& Vandemark, 1951 ; Johnson \& McCleskey, 1958). Some of the organisms possess flavoprotein peroxidases (Dolin, 1953, 1955, 1957; Niederpruem \& Hackett, 1958; Strittmatter, 1959). In the present work two catalytic activities were observed. 
The first type of activity was detected in eleven strains of Pediococcus pentosaceus and six of Leuconostoc mesenteroides, and in two strains of Lactobacillus plantarum ( NCDo 963, 965) not recorded in Table 1 which had been shown to have a weak $\mathrm{H}_{2} \mathrm{O}_{2}$-splitting activity by Dacre \& Sharpe (1956). This type of activity was most obvious when the organisms were grown aerobically on the basal medium or on

Table 1. Hydrogen peroxide formation, $\mathrm{H}_{2} \mathrm{O}_{2}$-splitting activity and manner of growth in soft agar of some lactic acid bacteria

\begin{tabular}{|c|c|c|c|c|c|c|}
\hline \multirow[b]{3}{*}{$\begin{array}{l}\text { Organism and } \\
\text { no. of strains }\end{array}$} & \multirow{2}{*}{\multicolumn{5}{|c|}{ Growth on media }} & $\begin{array}{l}\text { Type of } \mathrm{H}_{2} \mathrm{O}_{2^{-}} \\
\text {splitting activity; } \\
\text { no. of strains } \\
\text { positive }\end{array}$ \\
\hline & & & & & & $\overline{\text { Catalase }}$ \\
\hline & $\begin{array}{c}\text { Basal } \\
\text { medium }\end{array}$ & $\begin{array}{l}\text { Gluc- } \\
\text { ose }\end{array}$ & $\begin{array}{l}\text { Glyc- } \\
\text { erol }\end{array}$ & $\begin{array}{l}\text { Mann- } \\
\text { itol }\end{array}$ & $\begin{array}{l}\text { Sorb- } \\
\text { itol }\end{array}$ & $\begin{array}{l}\text { Pseudo- (haem- } \\
\text { Catalase requiring) }\end{array}$ \\
\hline
\end{tabular}

Genus Streptococcus

S. faecalis
S. faecium
S. faecium
S. faecium
S. durans

Genus Pediococcus

$P$. pentosaceus

P. acidilactici

P. halophilus

P. urinae-equi

$P$. cerevisiae

$-\mathrm{f}$

$+\mathbf{m}$

$+\mathbf{m}$

$+\mathbf{m}$

$-\mathbf{f}$
$-\mathbf{f}$

$-\mathbf{f}$

$-\mathbf{f} \quad-\mathbf{f}$

$$
+\mathrm{f}
$$

$+\mathbf{a}$

$+\mathbf{a}$

$+\mathbf{f}$

$+\mathrm{f}$

$+m$

$-\mathbf{f}$

$+\mathbf{a}$

$+f$

$+a$

.

•

$\begin{array}{ll}0 & 15 \\ 0 & 0 \\ 0 & 0 \\ 0 & 0 \\ 0 & 0\end{array}$

$+\mathrm{m}$

$+m$

$-\mathbf{f}+\mathbf{a}$

$-\mathbf{f}+\mathbf{a}$

$\begin{array}{ll}-\mathbf{f} & -\mathbf{f}\end{array}$

$+\mathbf{a}+\mathbf{p a}$

$+\mathbf{a}$

:

$\cdot 11$

110

$-\mathbf{f}$

$+\mathbf{a}$

$+$

0

0

Genus Aerococcus

$$
\text { A. viridans }
$$

$+\mathbf{a}$

+ pa

$+a$

$+\mathbf{a}$

$+\mathbf{a}$

0

o

Genus Leuconostoc

L. mesenteroides 72

(dextran formers)

L. mesenteroides 10

(non-dextran formers)

L. mesenteroides 8

(non-dextran formers)

L. dextranicum 2

L. citrovorum

\section{Glucose Fructose Sucrose Arabinose}

$\begin{array}{llll}-f & -f & -f & -f\end{array}$

6

0

$+f+f+f+f$

0

+ pa + pa + pa + pa

$0 \quad 8$

$\begin{array}{lll}-f & -f & -f\end{array}$

$0 \quad 0$

Genus Lactobacillus
L. brevis
L. brevis
L. brevis-like
L. buchneri
L. viridescens
L. cellobiosus
L. fermenti
L. plantarum
L. plantarum
L. casei
L. casei

22
8
2
25
2
2
14
15
8
5
3

Glucose

$$
\begin{aligned}
& \text { +pa } \\
& \text {-pa } \\
& + \text { pa* } \\
& + \text { pa } \\
& + \text { pa } \\
& + \text { pan } \\
& \text {-f } \\
& +\mathbf{f} \\
& -\mathbf{f} \\
& -\mathbf{f} \\
& +\mathbf{f}
\end{aligned}
$$

$\begin{array}{rr}\text { 0 } & \mathbf{2 2} \\ \mathbf{0} & 8 \\ \mathbf{0} & 2 \\ 0 & 0 \\ 0 & 2 \\ 0 & 0 \\ 0 & 0 \\ 0 & \mathbf{1 4} \\ 0 & 8 \\ 0 & 1 \\ 0 & 0\end{array}$

$\mathrm{H}_{2} \mathrm{O}_{2}$ formation: $+=$ detected, $-=$ not detected. Type of growth in soft agar: $\mathrm{f}=$ facultative, $=$ aerobic, $\mathrm{pa}=$ preferentially aerobic, pan $=$ preferentially anaerobic, $\mathrm{m}=$ microaerophilic, . = not utilized.

* Positive reaction on glucose MDO agar but negative on glucose HBD agar; attributed to strong catalase activity of these organisms when grown on HBD media. 
$\mathbf{0 . 0 5} \%(w / v)$ glucose nutrient agar; effervescence then began within 1 min. of adding $\mathrm{H}_{2} \mathrm{O}_{2}$. The activity was not observed in any organism grown on $1 \cdot 0 \%(\mathrm{w} / \mathrm{v})$ glucose nutrient agar or in any leuconostoc when grown anaerobically on any medium. When the initial $\mathrm{pH}$ value $(\mathbf{7 \cdot 0})$ of $0.05 \%(\mathrm{w} / \mathrm{v})$ glucose agar was lowered the activity of all strains diminished; at $\mathrm{pH} 6.0$ all were relatively active, at $\mathrm{pH} 5.0$ they were less active and at $\mathrm{pH} 4.5$ only some of the pediococci split $\mathrm{H}_{2} \mathrm{O}_{2}$. These pediococci were the only organisms which showed $\mathrm{H}_{2} \mathrm{O}_{2}$-splitting activity on $0.5 \%(\mathrm{w} / \mathrm{v})$ glucose agar (initially $\mathrm{pH} \mathrm{6.8)}$ ). The addition of haematin to the growth medium did not obviously affect the $\mathrm{H}_{2} \mathrm{O}_{2}$-splitting activity of any of these organisms.

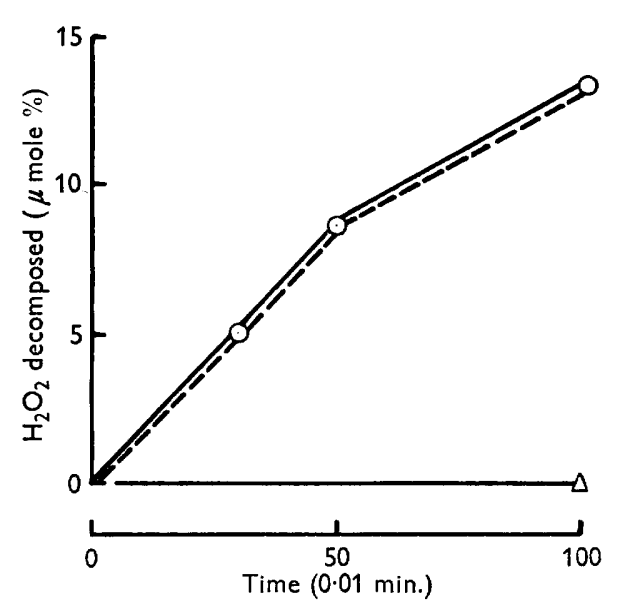

Fig. 1

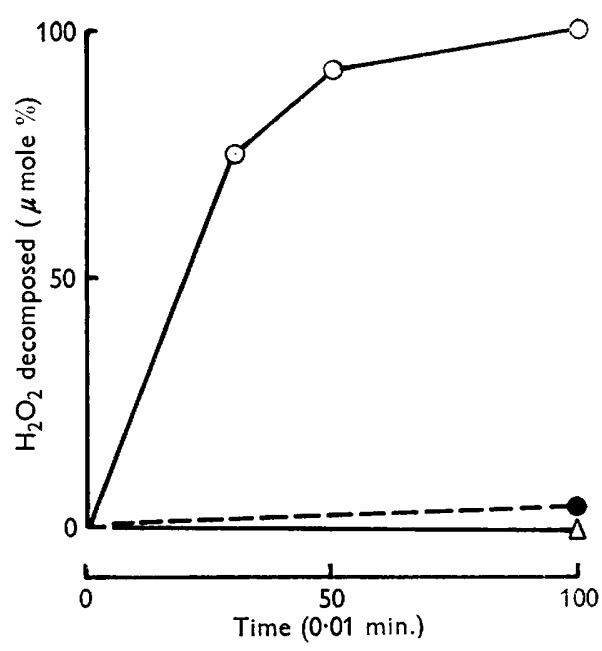

Fig. 2

Fig. 1. Pseudocatalase activity of suspensions of Leuconostoc citrovorum NCIB 7837 (Pediococcus pentosaceus). Each test-tube contained $120 \mu$ mole $\mathrm{H}_{2} \mathrm{O}_{2}$ and bacteria equivalent to $3.7 \mathrm{mg}$. dry wt. in $6 \mathrm{ml}$. $0.07 \mathrm{M}$-phosphate buffer (pH 6.5). Incubation at $30^{\circ}$. Residual $\mathrm{H}_{2} \mathrm{O}_{2}$ determined by method of Herbert (1955). $\bigcirc-O$, Untreated bacteria; - $\mathrm{O}_{-}-\mathrm{O}_{-}$, bacteria treated with $0.01 \mathrm{M}$-sodium azide; $\triangle-\triangle$, bacteria heated at $100^{\circ}$ for $2 \mathrm{~min}$.

Fig. 2. Haematin-requiring catalase activity of suspensions of Pediococcus acidilactici Rw 7. Each test-tube contained $120 \mu$ mole $\mathrm{H}_{2} \mathrm{O}_{2}$ and bacteria equivalent to $3 \cdot 3 \mathrm{mg}$. dry wt. in $6 \mathrm{ml}$. 0.07 M-phosphate buffer ( $\mathrm{pH} \mathrm{6.5)}$. Incubation at $30^{\circ}$. Residual $\mathrm{H}_{2} \mathrm{O}_{2}$ determined by method of Herbert (1955). $\mathrm{O}-\mathrm{O}=$ bacteria after $2 \mathrm{hr}$ incubation with $5 \mu \mathrm{g}$. haematin/ ml.; - - - = bacteria treated with $0.001 \mathrm{M}$-sodium azide after incubation with $5 \mu \mathrm{g}$. haematin $/ \mathrm{ml}$. for $2 \mathrm{hr} ; \triangle-\triangle=$ untreated bacteria.

The activity of suspensions of whole organisms and of water extracts of broken bacteria was examined. $\mathrm{H}_{2} \mathrm{O}_{2}$-splitting activity was completely eliminated by heating at $100^{\circ}$ for $2 \mathrm{~min}$. but was not noticeably inhibited by sodium azide or potassium cyanide added to a final concentration of 0.01 м 5 min. before the addition of $\mathrm{H}_{2} \mathrm{O}_{2}$. The reaction rates of a suspension of a pediococcus is shown in Fig. 1. Neither protoporphyrin IX nor haematin affected $\mathrm{H}_{2} \mathrm{O}_{2}$-splitting rates.

The insensitivity to cyanide and azide suggested that the enzyme was an atypical catalase, possibly not a haem derivative. This $\mathrm{H}_{2} \mathrm{O}_{2}$-splitting activity appears to be identical with that described by Delwiche (1961) and by Johnston \& Delwiche (1962). Delwiche (1961) examined a partially purified enzyme preparation obtained from 


\section{Peroxide and catalase in lactic acid bacteria}

a pediococcus and found it to be insensitive to $0.01 \mathrm{M}$-azide or $0.01 \mathrm{M}$-cyanide; no haem-pigment or flavin-coenzyme peaks were observed spectrophotometrically; acriflavin did not inhibit activity. These observations suggest that the enzyme was neither a haemoprotein nor a flavoprotein. Johnston \& Delwiche (1962) found a similar $\mathrm{H}_{2} \mathrm{O}_{2}$-splitting activity in some lactobacilli, leuconostocs, streptococci and additional pediococci. Earlier reports on weak catalase activity in pediococci (Felton, Evans \& Niven, 1953; Jensen \& Seeley, 1954), in strains of Lactobacillus plantarum (Dacre \& Sharpe, 1956), in strains of Leuconostoc mesenteroides (Langston \& Bouma, 1960) and in strains of Streptococcus faecalis (Langston \& Bouma, 1960) are probably similar to or have been shown by Johnston \& Delwiche (1962) to be similar to the type described by Delwiche (1961). To avoid confusion with a second type of activity demonstrable in bacteria grown in the presence of heated blood or haematin (Whittenbury, 1960) the first type will be referred to as pseudocatalase and the second as catalase.

The discovery of a haematin-requiring catalase activity in lactic acid bacteria originated from the observation that some heterofermentative lactobacilli formed $\mathrm{H}_{2} \mathrm{O}_{2}$ on MDO agar but not on $\mathrm{HBD}$ agar. Added $\mathrm{H}_{2} \mathrm{O}_{2}$ was split by cultures on HBD agar or HB agar but not by those on MDO agar or basal agar $+0.05 \%(w / v)$ glucose. A survey was made of organisms grown on HB agar and haematin agar. Table 1 shows the strains in which catalase activity was detected. Streptococcus faecalis and some of the lactobacilli had a weak action; they produced a vigorous effervescence only when heaped growth was placed into $\mathrm{H}_{2} \mathrm{O}_{2}$ solution. Pseudocatalase was not demonstrated in any strain which produced catalase.

Catalase formation was not prevented by altering the concentration of glucose in $\mathrm{HB}$ agar from 0.05 to $2.0 \%$ (w/v) nor by altering the initial $\mathrm{pH}$ value of $\mathrm{HB}$ agar containing $1 \%(\mathrm{w} / \mathrm{v})$ glucose from $\mathbf{7 \cdot 0}$ to $4 \cdot 5$. Some strains of Lactobacillus brevis which were active when grown aerobically were inactive or only weakly positive when grown anaerobically. Conversely, one strain of $L$. viridescens was active when grown anaerobically but inactive when grown aerobically. Replacement of haematin or heated blood by protoporphyrin IX $(50 \mu \mathrm{g} . / \mathrm{ml}$. medium $)$ and/or by various iron salts did not result in the development of detectable $\mathrm{H}_{2} \mathrm{O}_{2}$-splitting activity. It appears, therefore, that some lactic acid bacteria are able to form the apoenzyme of catalase and are able to synthesize catalase when provided with the preformed prosthetic group haem, but not with its immediate precursor protoporphyrin IX.

Washed suspensions of several strains, harvested from $1.0 \%(w / v)$ glucose agar, were tested for ability to form catalase when provided with haematin (5 $\mu \mathrm{g} . / \mathrm{ml}$.). The strains which were catalase-positive when grown on $\mathrm{HB}$ agar or on haematin agar developed $\mathrm{H}_{2} \mathrm{O}_{2}$-splitting activity within $2 \mathrm{hr}$ at $30^{\circ}$ with the exception of Streptococcus faecalis $\mathrm{H} 69 \mathrm{D} 5$, which did not develop $\mathrm{H}_{2} \mathrm{O}_{2}$-splitting activity; in most instances the activity was detectable within $5 \mathrm{~min}$. Strains which were catalasenegative when grown on HB agar showed no activity. Suspensions heated before or after addition of haematin, or pre-incubated for $20 \mathrm{~min}$. with haematin and a further 2 min. with azide or cyanide (at $0.001 \mathrm{M}$ ) did not split added $\mathrm{H}_{2} \mathrm{O}_{2}$, judged visually.

The $\mathrm{H}_{2} \mathrm{O}_{2}$-destroying rates found with haematin-treated organisms of Pediococcus acidilactici $\mathrm{RW} 7$ in the presence and absence of azide are shown in Fig. 2. In contrast to pseudocatalase, the catalase of this organism was almost completely inhibited 
by $0.001 \mathrm{M}$-sodium azide. The activity of suspensions of this pediococcus and of Lactobacillus plantarum NCIB 5914 after treatment with haematin and/or protoporphyrin IX was examined; the results are shown in Table 2. These suggest that the apoenzyme of catalase can combine with protoporphyrin IX or haematin and that, at least in the case of the pediococcus, neither appears to exchange with the other once the combination has been effected.

Table 2. The effect of different treatments on $\mathrm{H}_{2} \mathrm{O}_{2}$-splitting activities of suspensions of Lactobacillus plantarum NCIB 5914 and Pediococcus acidilactici $\mathrm{RW} 7$

Each test-tube contained $120 \mu$ mole $\mathrm{H}_{2} \mathrm{O}_{2}$ and bacteria equivalent to $3.3 \mathrm{mg}$. dry wt. pediococcus or $4.3 \mathrm{mg}$. dry wt. lactobacillus in $6 \mathrm{ml}$. of $0.07 \mathrm{M}$-phosphate buffer (pH 6.5). Organisms during treatment and testing were at $30^{\circ}$. Residual $\mathrm{H}_{2} \mathrm{O}_{2}$ was determined by method of Herbert (1955).

Previous treatment of bacterial suspensions

Haematin $(5 \mu \mathrm{g} . / \mathrm{ml}$. for $2 \mathrm{hr})$

Haematin $(5 \mu \mathrm{g} . / \mathrm{ml}$. for $2 \mathrm{hr})$ then heated at $100^{\circ}$ for $2 \mathrm{~min}$.

Haematin (50 $\mu \mathrm{g} . / \mathrm{ml}$. for $2 \mathrm{hr}$ )

Untreated

Protoporphyrin IX (5 $\mu \mathrm{g} . / \mathrm{ml}$. for $2 \mathrm{hr}$ )

Haematin $(5 \mu \mathrm{g} . / \mathrm{ml}$. for $15 \mathrm{~min}$. then

added protoporphyrin IX, $5 \mu \mathrm{g} . / \mathrm{ml}$.

for $2 \mathrm{hr}$ )

Protoporphyrin IX (5 $\mu \mathrm{g} . / \mathrm{ml}$. for $15 \mathrm{~min}$. then added haematin, $5 \mu \mathrm{g} . / \mathrm{ml}$. for $2 \mathrm{hr}$ )

Haematin $(5 \mu \mathrm{g} . / \mathrm{ml} .+$ protoporphyrin IX

$5 \mu \mathrm{g} . / \mathrm{ml}$. simultaneously for $2 \mathrm{hr}$ )

\begin{tabular}{|c|c|}
\hline $\begin{array}{l}\text { Lactobacillus } \\
\mathrm{H}_{2} \mathrm{O}_{2} \text { split in } 3\end{array}$ & $\begin{array}{l}\text { Pediococcus } \\
\text { sec. }(\mu \text { mole })\end{array}$ \\
\hline $62 \cdot 9$ & $74 \cdot 0$ \\
\hline $1 \cdot 8$ & $1 \cdot 8$ \\
\hline $21 \cdot 3$ & 74.0 \\
\hline 0 & 0 \\
\hline $3 \cdot 7$ & $2 \cdot 8$ \\
\hline $9 \cdot 3$ & $75 \cdot 8$ \\
\hline $9 \cdot 3$ & $7 \cdot 4$ \\
\hline $13 \cdot 0$ & $13 \cdot 0$ \\
\hline
\end{tabular}

Table 3. Distinguishing features of pseudocatalase-forming and haematin-requiring catalase-positive cultures of lactic acid bacteria

$\begin{array}{lcc} & \text { Pseudocatalase } & \begin{array}{c}\text { Haematin-requiring } \\ \text { catalase }\end{array} \\ \mathrm{H}_{2} \mathrm{O}_{2} \text { split by cultures grown on } & + & - \\ 0.05 \%(w / v) \text { glucose nutrient agar } & - & + \\ \mathrm{H}_{2} \mathrm{O}_{2} \text { split by cultures grown on } & & + \\ 1.0 \%(\mathrm{w} / \mathrm{v}) \text { glucose nutrient agar } & - & + \\ \text { containing haematin or heated blood } & & + \\ \mathrm{H}_{2} \mathrm{O}_{2} \text {-splitting activity inhibited by } & \\ \text { treating bacteria with } 0 \cdot 01 \mathrm{M} \text {-azide } & - & \\ \mathrm{H}_{2} \mathrm{O}_{2} \text {-splitting activity inhibited by } & \\ \text { treating bacteria with protopor- } & \\ \text { phyrin IX before treatment with } & \end{array}$

The foregoing observations show that two distinguishable forms of $\mathrm{H}_{2} \mathrm{O}_{2}$-splitting activity occur in some lactic acid bacteria; so far no organism has been found to possess both activities. The characteristics which separate the two activities are summarized in Table 3.

A comparison of the $\mathrm{H}_{2} \mathrm{O}_{2}$-splitting activity of some lactic acid bacteria and of some organisms which normally form catalase is given in Table 4. The pseudocatalase-positive lactic acid bacteria, Lactobacillus plantarum NCDo 965 and Leuco- 
nostoc citrovorum Nсів 7837 (Pediococcus pentosaceus), showed the slowest reaction rates. This result is like that of Johnston \& Delwiche (1962), who found that lactic acid bacteria which had a non-haem catalase were much less active than a strain of Escherichia coli; the catalase-positive lactic acid bacteria, on the other hand, showed an activity comparable with that of bacteria which normally produce catalase.

\section{Table 4. $A$ comparison of $\mathrm{H}_{2} \mathrm{O}_{2}$-splitting activities of various organisms}

Each tube contained $120 \mu$ mole $\mathrm{H}_{2} \mathrm{O}_{2}$ and bacteria of equivalent dry wt. $2 \cdot 5-5 \cdot 0 \mathrm{mg}$. in $6 \mathrm{ml}$. $0.07 \mathrm{M}$-phosphate buffer ( $\mathrm{pH} \mathrm{6.5)}$. Incubation at $30^{\circ}$. Residual $\mathrm{H}_{2} \mathrm{O}_{2}$ determined by method of Herbert (1955). A, grown on nutrient agar lacking added sugar; B, pseudocatalase-positive; grown on $0.05 \%(w / v)$ glucose agar; C, grown on $1.0 \%(w / v)$ glucose agar; washed bacteria incubated for $2 \mathrm{hr}$ with haematin $(5 \mu \mathrm{g} . / \mathrm{ml}$.).

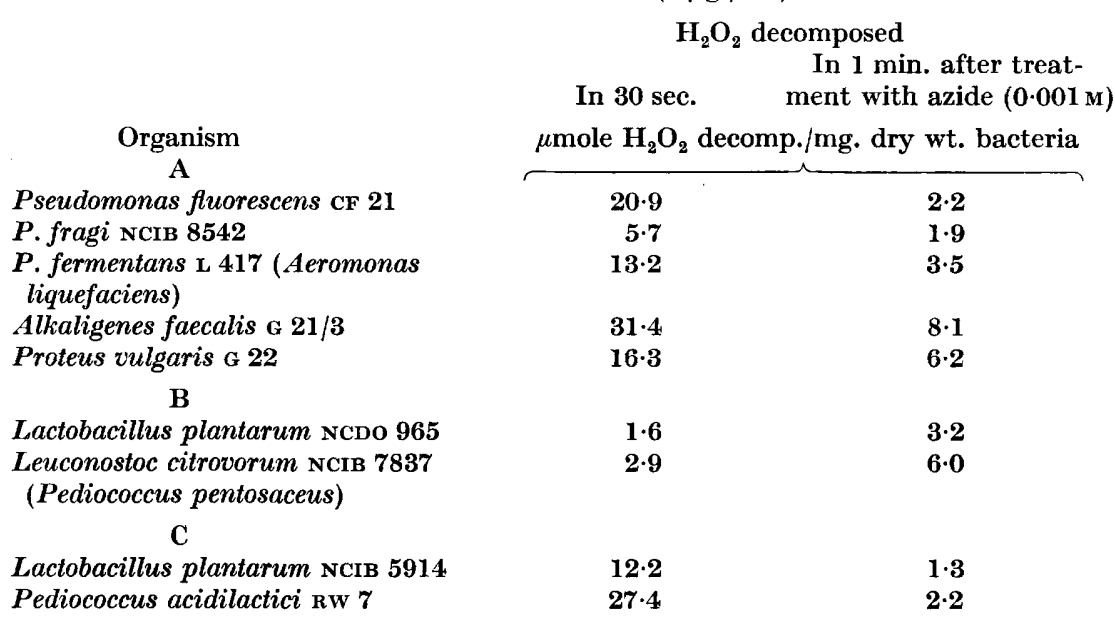

Dr J. R. Norris (personal communication) compared the $\mathrm{H}_{2} \mathrm{O}_{2}$-splitting enzymes of some of the present organisms, sent to him as acetone-dried preparations, with the catalases of various aerobic bacteria. After starch-gel electrophoresis the enzymes were detected by treating the gel with a preparation of $\mathrm{KI}$ and $\mathrm{H}_{2} \mathrm{O}_{2}$. Dr Norris found that: $(a)$ the catalase of lactic acid bacteria grown on media containing heated blood or haematin travelled at the same rate as the catalase of bacteria which normally form that enzyme; $(b)$ no catalase was detectable in the same lactic acid bacteria when these were grown in absence of heated blood or haematin; $(c)$ the pseudocatalase of lactic acid bacteria moved at a rate different from that of bacterial catalases. These findings indicate that the catalase of lactic acid bacteria is very similar to that of various aerobic organisms and that pseudocatalase is another type of enzyme. In the past, absence of catalase has been a useful diagnostic feature of the lactic acid bacteria. Recent findings have not diminished the value of this criterion, provided that the conditions of cultivation are appropriate. No organism among those examined was catalase-positive or pseudocatalase-positive when grown on $1 \%(\mathrm{w} / \mathrm{v})$ glucose agar without added haematin. 


\section{The relationship between hydrogen peroxide accumulation and the hydrogen peroxide-splitting activities}

Table 1 indicates that in the lactic acid bacteria examined there was little correlation between $\mathrm{H}_{2} \mathrm{O}_{2}$ production and ability to form catalase or pseudocatalase. Nevertheless, catalase formation was in certain instances clearly beneficial to the organisms. An outstanding example was provided by the eight leuconostocs which in glucose soft agar showed a strong preference for aerobic conditions. On the surface of solid glucose $(1 \%, w / v)$ nutrient agar these organisms produced little growth and were not viable after 1-2 days. The addition to that medium of $10 \mu \mathrm{g}$. haematin $/ \mathrm{ml}$. was sufficient to enable these organisms to form catalase, to produce good growth and to remain viable for a prolonged period; glucose HBD agar gave the same results. This further showed that, despite the formation of catalase, these organisms continued to produce $\mathrm{H}_{2} \mathrm{O}_{2}$. The pediococci which formed pseudocatalase likewise produced $\mathrm{H}_{2} \mathrm{O}_{2}$ on glycerol $\mathrm{HBD}$ agar. These observations suggest that catalase remains in and protects the cytoplasm of the organism while the oxidases occur in the plasma membrane, from which $\mathrm{H}_{2} \mathrm{O}_{2}$ can diffuse outwards. The $\mathrm{H}_{2} \mathrm{O}_{2}$ sensitive organisms showed excellent growth and viability on MDO agar. The insolubility of $\mathrm{MnO}_{2}$, which was protective, suggests that in this case the destruction of $\mathrm{H}_{2} \mathrm{O}_{2}$ occurred outside the bacterial cell.

\section{Plant juices as media for the organisms}

For lactic acid bacteria the ability to destroy $\mathrm{H}_{2} \mathrm{O}_{2}$ may be a significant survival factor in some natural environments. Organisms which produced catalase or pseudocatalase have been isolated from herbage where, if they proliferate, they will utilize substances liberated by the living or dead tissues. To test the suitability of plant juices as nutrients for these organisms, cultures were grown on the surface of solid media consisting of water agar to which had been added filter-sterilized or autoclaved extracts of the leaves of rye-grasses, cocksfoot or clovers, or extracts of potato tubers or turnips. The final concentrations of the plant juices were about $\mathbf{2 5 - 5 0} \%(\mathrm{v} / \mathrm{v})$. Organisms which formed catalase in the presence of haematin split added $\mathrm{H}_{2} \mathrm{O}_{2}$ when grown on the leaf extracts of grasses or clovers, but did not do so on potato or turnip extracts. Pseudocatalase-forming strains split added $\mathrm{H}_{2} \mathrm{O}_{2}$ when grown on any of the media; their pseudocatalase activity was eliminated by adding $1 \%(\mathrm{w} / \mathrm{v})$ glucose to the media. Strains which on artificial media did not split $\mathrm{H}_{2} \mathrm{O}_{2}$ were inactive when grown on the plant extracts. It seems reasonable to suppose that catalase may be formed from an iron porphyrin in leaf juices, thus enabling certain organisms to proliferate in a herbage environment without succumbing to $\mathrm{H}_{2} \mathrm{O}_{2}$ poisoning.

\section{The formation of cytochromes}

Jensen (1957) described a streptomycin-resistant mutant of Micrococcus pyogenes var. aureus (Staphylococcus aureus) which did not synthesize haem but was able to form catalase and cytochromes when provided with haem. Since some lactic acid bacteria appeared similar in that they were able to form catalase when provided with haematin, their ability to form cytochromes as well was examined. Physiological tests gave negative results. Dense suspensions of organisms grown in a 
succinate medium containing a trace of glucose did not reduce 2,3,5-triphenyltetrazolium chloride in the presence of succinate; none oxidized $p$-phenylenediamine (Nadi reagent). Organisms which were grown aerobically with haematin and nitrate in the medium and then incubated anaerobically did not form nitrite (or, if they did so, no more vigorously than when grown in absence of haematin). The fact that certain strains formed $\mathrm{H}_{2} \mathrm{O}_{2}$ on glucose $\mathrm{HBD}$ agar suggests that cytochromes, if formed, were not significantly functioning.

\section{Table 5. Cytochrome content of some lactic acid bacteria}

When cytochromes were not observed, presence or absence of porphyrin compounds was checked by treatment with pyridine.

\section{$\mathrm{H}_{2} \mathrm{O}_{2}$-splitting characteristic and organism \\ Catalase + , pseudocatalase - \\ Lactobacillus plantarum NCIB 5914}

L. brevis NCIB 947

Leuconostoc mesenteroides NCIB 8018 (Pediococcus acidilactici)

L. mesenteroides RW 1 (non-dextran forming)

Streptococcus faecalis н 69 D5

Catalase -, pseudocatalase -

Lactobacillus plantarum NCIB 6105

Catalase - , pseudocatalase +

Leuconostoc citrovorum NCIB $\mathbf{7 8 3 7}$

(Pediococcus pentosaceus)

L. mesenteroides $\mathrm{RW} 66$

\section{*Medium from which bacteria were harvested}

$\begin{array}{cc}\begin{array}{c}\text { Cytochromes } \\ \text { detected }\end{array} & \text { Formation } \\ \text { after adding } & \text { of pyridine } \\ \mathrm{Na}_{2} \mathrm{~S}_{2} \mathrm{O}_{4} & \text { haemochromogen }\end{array}$

A
B
A
B
A
B
A
B

$\mathbf{A}$

B

A

B

C

C
None

$a_{2} b_{1}$

None

$b_{1}$

None

None

None

$$
a_{2} b_{1}
$$
(very weak bands)

None

$a_{1} a_{2} b_{1}$

$b_{1}$ Very weak

bands

$b_{1}$ Very weak

bands

None

None
Trace

None

None

Trace

None

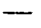

None
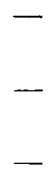

None

$* A=1 \cdot 0 \%(w / v)$ glucose agar, $B=1 \cdot 0(w / v)$ glucose agar containing heated blood, $C=0.05 \%$ $(w / v)$ glucose agar.

Suspensions of a few strains of lactic acid bacteria were sent to Dr E. F. Hartree (Molteno Institute, Cambridge), who examined them for cytochrome content by the low temperature method (Keilin \& Hartree, 1949, 1950); the results are given in Table 5. Four of the organisms which formed catalase possessed cytochromes when grown in the presence of heated blood but not in its absence. Perhaps heavier suspensions might have revealed that all four strains possessed the $a$ and $b$ types

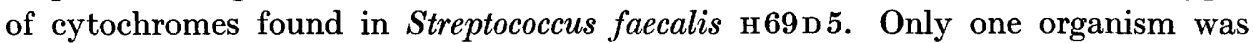
tested which was unable to attack $\mathrm{H}_{2} \mathrm{O}_{2}$; it showed a weak cytochrome $b 1$ band whether grown in the presence or absence of heated blood. The two pseudocatalasepositive organisms grown on $\mathbf{0 . 0 5} \%(\mathrm{w} / \mathrm{v})$ glucose agar formed no cytochromes and contained no haem demonstrable as pyridine-haemochromogen. It thus appears 
possible that cytochromes may be formed by some lactic acid bacteria under certain conditions of cultivation. Whether these cytochromes are functional, vestigial, or artifacts resulting from the cultural conditions, remains to be determined.

\section{DISCUSSION}

Enzymic and growth studies are revealing the ability of many lactic acid bacteria to utilize oxygen with benefit to themselves and to dispose of the $\mathrm{H}_{2} \mathrm{O}_{2}$ which may be formed. Dolin (1961) in discussing this question suggested that clostridia and lactic acid bacteria represent different stages in physiological development (evolution) and that, although both types of organisms use similar respiratory systems, the lactic acid bacteria are more successfully adapted to aerobic conditions. Streptococci, he considered, may be related to the more aerobic bacteria through the pediococci, presumably because of the finding (Dolin, 1955) that Streptococcus faecalis possesses a cytochrome $c$ reductase but no demonstrable cytochromes, whilst pediococci appear to possess a cytochrome $c$-cytochrome oxidase activity, since they oxidize $p$-phenylenediamine (Jensen \& Seeley, 1954). This argument, however, is questionable. The possession by $S$. faecalis of a cytochrome $c$ reductase does not necessarily imply that reduction of cytochrome $c$ is or was the true physiological role of such an enzyme. Also, the ability of pediococci to oxidize $p$-phenylenediamine is only indirect evidence of the possible presence of cytochrome $c$ and cytochrome oxidase. No oxidation of $p$-phenylenediamine by similar pediococci was observed in the present work. Clearly it is necessary that direct evidence of the presence or absence of cytochromes should be provided. The suspensions of two strains of pediococci examined in the present work did not contain detectable cytochromes (Table 5). However, the available evidence, though fragmentary, suggests that some lactic acid bacteria do possess the rudiments of a respiratory system. The ability of some to form haemoproteins when provided with a source of iron porphyrin suggests that, rather than adapting to aerobic conditions as implied by Dolin (1961), they have evolved retrogressively from facultatively aerobic haemoprotein-forming organisms. Their survival in nature could be related to their specialization for life in distinctly acid, sugar-containing environments from which oxygen is frequently absent. A study of iron porphyrin-less mutants of haemoprotein-forming facultative aerobes might reveal some close relationships with lactic acid bacteria. It may prove difficult, for instance, to distinguish the haematin-less mutant of Staphylococcus aureus (Jensen, 1957) from pediococci or aerococci.

The author wishes to thank DrT. Gibson for advice and encouragement given during this work and for helpful criticism given during the preparation of the manuscript. Thanks are due to Dr R. G. Board for providing strains of Gram-negative bacteria, to the late Dr P. M. Frances Shattock and Dr M. Elisabeth Sharpe for providing some of the strains of lactic acid bacteria studied, and to Dr E. F. Hartree for determining the cytochrome content of some of the organisms. 


\section{REFERENCES}

Berger, U. (1953). Weitere Untersuchungen zur Frage einer antibakteriellen Speichelwirkung. Z. Hyg. Infektkr. 136, 94.

Dacre, J. C. \& Sharpe, M. E. (1956). Catalase production by lactobacilli. Nature, Lond. 178, 700 .

Delwiche, E. A. (1961). Catalase of Pediococcus cerevisiae. J. Bact. 81, 416.

Dobrogosz, W. J. \& Stone, R. W. (1959). Glycerol metabolism of pediococci isolated from alfalfa silages. Bact. Proc. p. 111.

Dolin, M. I. (1953). The oxidation and peroxidation of $\mathrm{DPNH}_{2}$ in extracts of Streptococcus faecalis, 10c1. Archs. Biochem. 46, 483.

Dolin, M. I. (1955). The DPNH-oxidizing enzymes of Streptococcus faecalis II. The enzymes utilizing oxygen, cytochrome c, peroxide and 2,6-dichlorophenol-indophenol or ferricyanide as oxidants. Archs. Biochem. 55, 415.

Dol.in, M. I. (1957). The Streptococcus faecalis oxidases for reduced diphosphopyridine nucleotide. II. Isolation and properties of a flavin peroxidase for reduced diphosphopyridine nucleotide. J. biol. Chem. $225,557$.

Dolin, M. I. (1961). Cytochrome-independent electron transport enzymes of bacteria. In The Bacteria. Ed. by I. C. Gunsalus \& R. Y. Stanier, vol. 2, p. 425. London: Academic Press, Inc.

Douglas, H. C. (1947). Hydrogen peroxide in the metabolism of Lactobacillus brevis. J. Bact. 54, 272.

Felton, E. A., Evans, J. B. \& Niven, C. F. Jr.. (1953). Production of catalase by pediococci. J. Bact. 65, 481 .

Greison, E. C. \& Gunsalus, I. C. (1943). Hydrogen peroxide destruction by streptococci. J. Bact. 45, 16.

Gunsalus, I. C. \& Sherman, J. M. (1943). The fermentation of glycerol by streptococci. J. Bact. 45, 155.

Gunsalus, I. C. \& Umbreit, W. W. (1945). The oxidation of glycerol by Streptococcus faecalis. J. Bact. 49, 347.

Herbert, D. (1955). Catalase from bacteria. In Methods in Enzymology. Ed. by S. P. Colowick \& N. O. Caplan, vol. 2, p. 784. New York: Academic Press Inc.

Jensen, E. M. \& Seeley, H. W. (1954). The nutrition and physiology of the genus Pediococcus. J. Bact. 67, 484.

JENSEN, J. (1957). Biosynthesis of hematin compounds in a hemin requiring strain of Micrococcus pyogenes var. aureus. J. Bact. 73, 324.

Johnson, M. K. \& McCleskey, C. S. (1957). Studies on the aerobic carbohydrate metabolism of Leuconostoc mesenteroides. J. Bact. 74, 22.

Johnson, M. K. \& MCCleskey, C. S. (1958). Further studies on the aerobic metabolism of Leuconostoc mesenteroides. J. Bact. 75, 98.

Johnston, M. A. \& Delwiche, E. A. (1962). Catalase of the Lactobacillaceae. J. Bact. 83, 936.

Keilin, D. \& Hartree, E. F. (1949). Effect of low temperature on the absorption spectra of haemoproteins; with observations on the absorption spectrum of oxygen. Nature, Lond. 164, 254.

Keilin, D. \& Hartree, E. F. (1950). Further observations on absorption spectra at low temperatures. Nature, Lond. 165, 504.

Kneteman, A. (1947). A reaction on the formation of hydrogen peroxide by microorganisms in solid media. Antonie van Leeuwenhoek, 13, 55.

Kraus, F. W., Nickerson, J. F., Perry, W. I. \& Walker, A. P. (1957). Peroxide and peroxidogenic bacteria in human saliva. J. Bact. 73, 727.

Langston, C. W. \& Bouma, C. (1960). A study of the microorganisms from grass silage. I. The cocci. Appl. Microbiol. 8, 212.

Nakagawa, A. \& Kitahara, K. (1959). Taxonomic studies on the genus Pediococcus. J. gen. appl. Microbiol. 5, 95.

Niederpruem, D. J. \& Hackett, D. P. (1958). The oxygen affinity of a flavin oxidase involved in the respiration of Streptococcus faecalis. Plant Physiol. 33, 113. 
Penfold, W. J. (1922). 'The action of the pneumococcus on aromatic amino bodies. Med. J. Aust. 9 (2), 120.

Seeley, H. W. \& Vandemark, P. J. (1951). An adaptive peroxidation by Streptococcus faecalis. J. Bact. 61, 27.

Strittmatter, C. F. (1959). Flavin-linked oxidative enzymes of Lactobacillus casei. J. biol. Chem. 234, 2794.

Whittenbury, R. (1960). Two types of catalase-like activity in lactic acid bacteria. Nature, Lond. 187, 433.

Whittenbury, R. (1963). The use of soft agar in the study of conditions affecting substrate utilization by lactic acid bacteria. J. gen. Microbiol. 32, 375 . 